\author{
Blanka Lęt \\ Poznań University of Economics and Business \\ e-mail: blanka.let@ue.poznan.pl \\ ORCID: 0000-0001-5107-1456
}

\title{
LINKAGES BETWEEN AMERICAN AND EUROPEAN PUBLICLY TRADED AIRLINE COMPANIES - EVIDENCE RESULTING FROM THE DIEBOLD-YILMAZ METHOD
}

DOI: $10.15611 / \mathrm{pn} .2020 .4 .08$

JEL Classification: G15, L93

\section{(C) 2020 Blanka Łęt}

This is an open access article distributed under the Creative Commons Attribution-NonCommercial-NoDerivs license (http://creativecommons.org/licenses/by-nc-nd/3.0/)

Quote as: Łęt, B. (2020). Linkages between American and European publicly traded airline companies - evidence resulting from the Diebold-Yilmaz method. Prace Naukowe Uniwersytetu Ekonomicznego we Wrocławiu, 64(4).

\begin{abstract}
In this paper, the author implemented the Diebold and Yilmaz approach to analyse the connectedness between the major American and European publicly traded airline companies. The author calculated the return and volatility spillover index for the whole sample using a dynamic rolling sample analysis. The results show that all airlines are significantly linked but there is a clear division into two markets. It was found that return spillovers are more intensive than volatility spillovers. Moreover, the average connectedness level is higher in the U.S. market for returns as well as for volatility. An increase of connectedness occurred due to the certain events: issues linked with the condition of the global economy and long-term crude oil price changes.
\end{abstract}

Keywords: airlines, connectedness, Diebold-Yilmaz approach, spillovers.

\section{Introduction}

Several common factors have an impact on airline companies' profits: the price of jet fuel, labour costs, changing demand linked with the condition of the global economy, bad weather issues, and political instability. Undoubtedly, the crisis in the air services market appeared with the emergence of the risk of the COVID-19 Coronavirus pandemic. One could see the uncertainty associated with the emergence of the virus in Europe and the United States, and then the real financial problems after the suspension of many international and domestic air connections. 
Given the above factors, one would expect that the listings in the stock markets of airline companies should also be strongly connected. However, there are also regional discrepancies, such as consumer preferences or local events that affect companies' profits. On the other hand, some factors affect only a selected firm performance. For example, in the case of major accidents, there is a possibility that a company's bad reputation will prompt investors to change their position and cause a decrease in its market value.

There are numerous papers devoted to the dynamics of the stock prices of airline companies and the factors that influence their dynamics. Gillen and Lall (2003) focused on the international transmission of shocks in the airline industry in the aftermath of the September 11th attacks. They analysed the market value of U.S. and non-U.S. airlines and found a negative impact on the mean abnormal returns of practically every airline in the sample, but this impact varied across regions. Similar results were obtained by Carter and Simkins (2004) who analysed the stock-price reaction of publicly traded companies (18 U.S. airlines, seven international airlines, and four airfreight carriers) in the air-transport industry following the September 11th attacks as an example of an unexpected, catastrophic event. They used the multivariate regression model methodology to test the hypothesis that the market viewed the attack as having important implications for airlines, and they tried to determine whether the market reaction was the same for each airline company. They found statistically significant, negative abnormal returns for each of the airlines studied and smaller negative returns for airfreight firms.

Gong et al. (2008) studied the issue of the existence of transnational information transfers associated with earnings announcements for close competitors in the airline industry. They revealed an interesting phenomenon: inter-firm rivalry causes stock market linkages across national borders. Thus, their research shows the existence of linkages within the airline industry.

Many studies have attempted to explore the linkage between oil prices and the transportation sector, including airlines. The results of previous research are mixed. Nandha and Brooks (2009) used monthly data of the WTI oil price and the transport sector indices for 38 countries. The results of this study show that the oil price is a significant factor for the transport sector in the case of mature economies i.e. belonging to 'Developed', 'Europe' and 'G7' groupings and the sign of this effect is negative. The study was further extended by Mohanty et al. (2014) and Killins (2020). Mohanty et al. (2014) analysed, among others, the U.S. airline sector using the Fama-French-Carhart model. They found that oil price exposure is significantly negative for airlines, and during the global financial crisis of 12/2007-06/2009 this effect was stronger. Moreover, using monthly data and an extended Fama-French factor model, Killins (2020) found that airlines in the USA were negatively impacted by positive movements in the WTI, but there was a limited impact on Canadian airlines. Hsu (2017) also analysed how fuel price shocks affect airlines' stock returns. He applied the GJR-GARCH model with additional variables and found that 
U.S. airlines' stock returns had a negative relationship with oil price changes. In most cases, fuel shocks triggered higher volatility. On the other hand, Kristjanpoller and Concha (2016) analyzed daily data of 56 airlines associated with the IATA from different regions of the world. They found that fuel price has an impact on airline prices, but according to their findings, this effect was in most cases positive, i.e. an increase in fuel price is followed by an increase in airline stock prices. The authors explained these results referring to the idea of market inertia and they argued that increases in the oil price are signals of better economic growth in the future. Yun and Yoon (2019) also showed that crude oil's impact depends on the type of airlines under consideration. They focused on the Chinese and Korean airlines' stock returns and volatilities and their relation to the oil prices. The main result of their study, in which the multivariate GARCH model was used, is that the volatility spillover effect between the crude oil price and airlines' stock price is more significant than the return spillover effect. Moreover, the return of the WTI crude oil price had no impact on the stock price return of Korean Air and Asian Airlines, but a negative impact on the stock price return of Air China and China Eastern Airlines.

This paper tries to extend previous works devoted to the dynamics of stock prices of airline companies and to this end, measured spillovers in returns and return volatilities using the Diebold and Yilmaz (2012) approach. Earlier papers using this method were devoted to the analysis of global equity market (Diebold and Yilmaz, 2009; Zhou et al., 2012), transmission in and between stock markets, bonds, foreign exchange markets and commodities (Diebold and Yilmaz, 2012; Awartani and Maghyereh, 2013; Antonakakis, 2012; Antonakakis and Kizys, 2015; Kang, McIver, and Yoon 2017; Barunik, Kočenda, and Vácha, 2016; Batten, Ciner, and Lucey. 2015), connectedness between financial institutions (Diebold and Yilmaz, 2014, 2016; Demirer, Diebold, Liu, and Yilmaz, 2018), CDS spreads (Alter and Beyer, 2014), cryptocurrencies (Kliber and Włosik, 2019) and others. The results of the abovementioned studies show that the connectedness index changes over time and that the detected dynamics are a result of certain events that affect investors' decisions.

The study measured the level of connectedness between returns and volatilities for the major publicly traded airline companies in Europe and the United States. The following research questions were set:

RQ1: Do airlines stock prices and volatilities react in the same manner to shocks coming from other regions as to the internal region shocks?

RQ2: Are prices spillovers stronger, compared to the volatility spillovers?

RQ3: What events lead to an increase in connectedness?

The remainder of the paper is organized as follows. First, the methodology employed in this study is presented then the data and the results of price and volatility spillovers are described. The analysis was extended by taking into account shocks transmitted from crude oil prices and the main capital market. The last section contains the concluding remarks. 


\section{Methodology: the Diebold and Yilmaz approach}

Diebold and Yilmaz (2009) introduced a return and volatility spillover index using forecast error variance decomposition from the VAR (vector autoregressive) model. An extension and improvement of this work (Diebold and Yilmaz, 2012), was based on the KPPS (Koop, Peseran, and Potter, 1996; Peseran and Shin, 1998) generalized vector autoregressive framework, in which forecast-error variance decompositions are invariant to the variable ordering.

The first step of this method is to build a covariance stationary $N$-variable $\operatorname{VAR}(p)$ model

$$
x_{t}=\sum_{i=1}^{p} \Phi_{i} x_{t-i}+\varepsilon_{t},
$$

where $x_{t}=\left(x_{1 t}, \ldots, x_{N t}\right), \varepsilon \sim(0, \Sigma), \Phi_{i}$ is a square parameter matrix of order $N$. The next step is to find the MA (moving average) representation

$$
x_{t}=\sum_{i=0}^{\infty} \mathrm{A}_{i} \varepsilon_{t-i},
$$

where $A_{i}$ are MA coefficients, wherein $A_{0}$ is the square identity matrix of order $N, A_{i}=0$ for $i<0$ and for $i>0, A_{i}$ satisfies the recursive equation $A_{i}=\Phi_{1} A_{i-1}+\Phi_{2} A_{i-2}+\cdots+\Phi_{p} A_{i-p}$. For a detailed analysis of the generalized forecast error variance decomposition based on the MA representation, see Peseran and Shin (1998).

Diebold and Yilmaz (2012) defined own variance shares as the fractions of the $H$-step-ahead error variances in forecasting $x_{i}$ due to shocks to $x_{i}$, but in this paper the author attach great importance to spillovers defined as the fractions of the $H$-step-ahead error variances in forecasting $x_{i}$ due to shocks to $x_{j}$, when $i \neq j$.

Let $\theta_{i j}^{g}(H)$ denote the KPPS $H$-step-ahead forecast error variance decompositions from the generalized vector autoregressive framework calculated as:

$$
\theta_{i j}^{g}(H)=\frac{\sigma_{j j}^{-1} \sum_{h=0}^{H-1}\left(e_{i}^{\prime} A_{h} e_{j}\right)^{2}}{\sum_{h=0}^{H-1}\left(e_{i}{ }^{\prime} A_{h} \Sigma A_{h}^{\prime} e_{i}\right)},
$$

Where $\sigma_{j}$ denotes the standard deviation of the error term for the $j$-th equation and $e_{j}$ is the vector such that one is the $j$-th element and zeros otherwise. The above value is then normalized using the formula:

$$
\tilde{\theta}_{i j}^{g}(H)=\frac{\theta_{i j}^{g}(H)}{\sum_{j=1}^{N} \theta_{i j}^{g}(H)} .
$$

This construction ensures that $\sum_{j=1}^{N} \tilde{\theta}_{i j}^{g}(H)=1$ and $\sum_{i, j=1}^{N} \tilde{\theta}_{i j}^{g}(H)=N$.

The total spillover index $S^{g}(H)$ measures the contribution of spillovers of shocks across all asset classes to the total forecast error variance: 


$$
S^{g}(H)=\frac{\sum_{\substack{i, j=1 \\ i \neq j}}^{N} \widetilde{\theta}_{i j}^{g}(H)}{N} \cdot 100 .
$$

One can also calculate directional spillovers received by market $i$ from all other markets $j$ :

$$
S_{i \cdot}^{g}(H)=\frac{\substack{\sum_{j=1}^{N} \widetilde{\theta}_{i j}^{g}(H) \\ j \neq i}}{N} \cdot 100
$$

and directional spillovers transmitted by market $i$ to all other markets $j$ :

$$
S_{\cdot i}^{g}(H)=\frac{\substack{\sum_{j=1}^{N} \widetilde{\theta}_{j i c}^{g}(H) \\ j \neq i}}{N} \cdot 100 .
$$

The set of directional spillovers provides a decomposition of the total spillover index $S^{g}(H)$ to those coming from a particular source or to the selected receiver. Furthermore, there are following relationships between indexes (5), (6) and (7):

$$
S^{g}(H)=\frac{\sum_{i=1}^{N} S_{i \cdot}^{g}(H)}{N}
$$

and

$$
S^{g}(H)=\frac{\sum_{i=1}^{N} S_{\cdot i}^{g}(H)}{N}
$$

\section{Data and results}

The data consists of the daily prices of eight major European and American publicly traded companies: Air France (AF), Lufthansa (LHA), International Airlines Group (IAG), Ryanair (RYA), United Airlines Holdings (UAL), American Airlines Group (AAL), Delta Air Lines (DAL), and Southwest Airlines (LUV). Moreover, the second part of the analysis took into account the DJIA index that serves as a barometer of stock market performance and crude oil represented by West Texas Intermediate oil futures prices to reflect jet fuel prices. The data cover the period from 3 May 2007 to 28 February 2020.

All the calculations used the daily logarithmic returns for stock $i$ on day $t$ :

$$
r_{i, t}=100 \cdot \ln \left(\frac{P_{i, t}}{P_{i, t-1}}\right),
$$

where $P_{i, t}$ is the price of the stock $i$ on day $t$, and estimate of the annualized daily percent volatility using the Parkinson (1980) High Low Range Volatility estimator: 


$$
\hat{\sigma}_{i, t}=100 \cdot \sqrt{365 \cdot \frac{1}{4 \ln 2}\left[\ln \left(\frac{P_{i, t}^{\max }}{P_{i, t}^{\min }}\right)\right]^{2}},
$$

where $P_{i, t}^{\max }\left(P_{i, t}^{\max }\right)$ is the maximum (minimum) price for stock $i$ on day $t$.

\subsection{Preliminary results}

The author plotted daily returns and volatilities in Figure 1 and provided summary statistics of the returns in Table 1 and formulated several findings. United Airlines and American Airlines were the most volatile and had the highest excess kurtosis related to the frequent occurrence of extremal returns. All volatilities were higher during the 2008 crisis, but clearly it was the U.S. that market reacted more strongly.

Table 1. Descriptive statistics of returns

\begin{tabular}{|l|c|c|c|c|c|c|c|c|}
\hline & RYA & IAG & LHA & AF & UAL & AAL & DAL & LUV \\
\hline Mean & 0.02 & 0.00 & -0.02 & -0.05 & 0.02 & -0.02 & 0.03 & 0.04 \\
\hline Std. dev. & 2.37 & 2.61 & 2.14 & 2.77 & 4.19 & 4.28 & 3.32 & 2.12 \\
\hline Skewness & -0.35 & -0.48 & -0.32 & -0.10 & 0.00 & 0.20 & 0.01 & -0.49 \\
\hline Excess kurt. & 8.45 & 5.61 & 2.91 & 2.76 & 21.87 & 11.00 & 8.64 & 6.45 \\
\hline
\end{tabular}

Source: based on own research.

The study also checked stationarity of examined returns and volatilities using the ADF and KPSS tests. Since in the case of the volatilities series, the KPSS test results led to the rejection of the null hypothesis of stationarity, the author decided to calculate a differenced series and test them again. The test results confirmed that these series are stationary, therefore all the results of further analysis refer to daily logarithmic returns and differenced volatilities. 
RYA

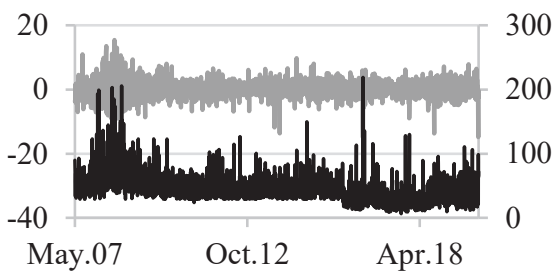

LHA

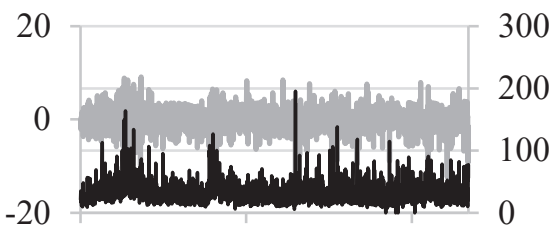

May.07 Oct.12 Apr.18

IAG

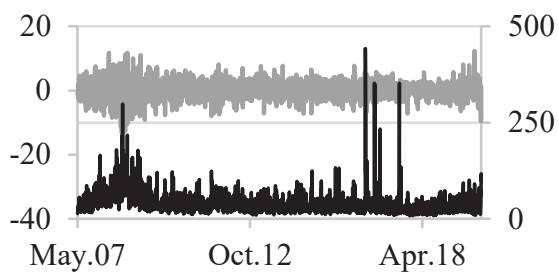

$\mathrm{AF}$

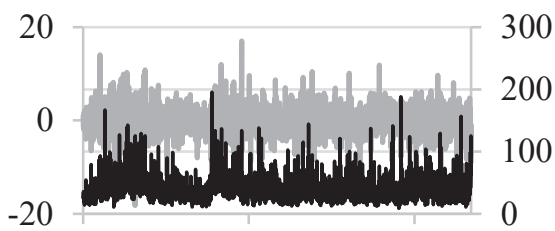

May.07 Oct.12 Apr.18

AAL

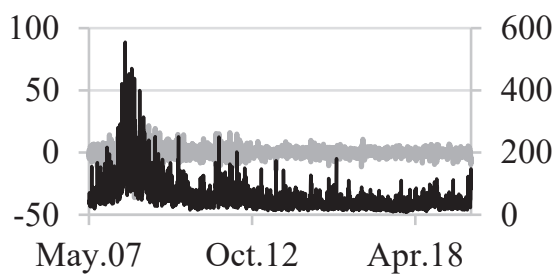

LUV

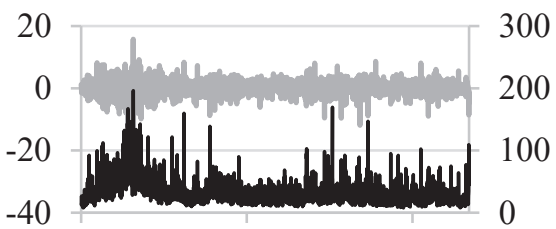

May.07 Oct.12 Apr.18

300

200

100 0

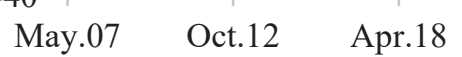

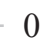

\section{0}

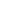




\subsection{Diebold and Yilmaz connectedness}

\subsubsection{Airline market}

The author applied the methodology discussed in Section 1 using a vector autoregressive model of order 4 and ten-day-ahead forecasts. As Diebold and Yilmaz (2012) pointed out, their method is not sensitive to the choice of the order of the VAR or the choice of the forecast horizon. Tables 2 and 3 present spillovers between the analysed series. Each $i j$ th entry is the estimated share to the forecast error variance of asset $i$ coming from asset $j$. The values in the column "From others" refer to the off-diagonal row sums (calculated according to formula (6)), and similarly the row "To others" contains values of the off-diagonal column sums (calculated according to formula (7)). Moreover, the study calculated the spillover index (SI) according to formula (5) that represents the contribution of spillovers of shocks across all asset classes to the total forecast error variance. Furthermore, the last rows of tables contain spillover indices calculated separately to the European and American markets using the off-diagonal sums of elements referred to airlines operating in the same regions (Europe $\rightarrow$ Europe and USA $\rightarrow$ USA) and operating in different regions (Europe $\rightarrow$ USA and USA $\rightarrow$ Europe), which show how shocks are transmitted across markets.

The value of the return spillover index in the right bottom corner of Table 2 indicates that, on average, $62.10 \%$ of the return forecast errors variance in the airline market come from spillovers, while for the volatility this index in Table 3 is much lower and equals $32.89 \%$. A similar pattern emerges when one takes into account regional indices or transatlantic indices of return and volatility spillovers. What can be noted, is that return and volatility connectedness between European airlines is weaker than between American ones. Moreover, the interactions are stronger for close competitors, and there is a clear division into two markets. For example, the European spillover index is around $40 \%$, while the index that measures the transmission of shocks from American to European airlines is half the size. Furthermore, the level of transatlantic spillover indices from the USA to Europe is slightly higher than the spillover indices from Europe to the USA.

The results indicate that there is the following ranking of return spillover emitters: DAL, UAL, AAL, IAG, LHA, LUV, AF, RYA, and volatility spillover emitters: DAL, AAL, UAL, LHA, AF, LUV, IAG, RYA. The undisputed leader of the spillover rankings is Delta Airlines, one of the largest airlines in the United States by passengers carried, fleet size, and market capitalization.

One can treat the discussed results as an unconditional pattern since the tables refer to the full sample. In the next step, the author estimated volatility spillovers using 200-day rolling samples. Figure 2 presents the dynamics of the returns spillover index and Figure 3 presents the volatility spillover index in which one can observe a similar pattern as in the case of the returns spillover index. One can see that the indices are quite stable over time, but there are also periods of growth in connectedness that can be attributed to specific events. 
Table 2. Return spillover table (airlines)

\begin{tabular}{|l|c|c|c|c|c|c|c|c|c|}
\hline & RYA & IAG & LHA & AF & UAL & AAL & DAL & LUV & $\begin{array}{c}\text { From } \\
\text { others }\end{array}$ \\
\hline RYA & 47.90 & 14.57 & 11.18 & 8.88 & 4.47 & 4.24 & 4.77 & 3.99 & 52.10 \\
\hline IAG & 11.39 & 37.29 & 15.23 & 13.67 & 5.26 & 5.45 & 5.81 & 5.91 & 62.71 \\
\hline LHA & 8.93 & 15.65 & 38.04 & 18.76 & 4.20 & 4.50 & 4.58 & 5.34 & 61.97 \\
\hline AF & 7.51 & 14.83 & 19.76 & 40.27 & 4.09 & 4.51 & 4.28 & 4.76 & 59.74 \\
\hline UAL & 2.42 & 3.81 & 2.65 & 2.53 & 33.72 & 20.83 & 21.86 & 12.18 & 66.28 \\
\hline AAL & 2.47 & 4.10 & 2.85 & 2.86 & 21.17 & 33.97 & 19.94 & 12.64 & 66.03 \\
\hline DAL & 2.82 & 4.43 & 3.09 & 2.74 & 21.38 & 19.14 & 32.73 & 13.67 & 67.27 \\
\hline LUV & 2.73 & 4.99 & 4.26 & 3.64 & 14.17 & 14.56 & 16.34 & 39.30 & 60.70 \\
\hline To others & 38.27 & 62.38 & 59.03 & 53.07 & 74.73 & 73.22 & 77.59 & 58.48 & SI 62.10 \\
\hline & \multicolumn{7}{|l}{ SI (Europe $\rightarrow$ Europe) 40.10} & \multicolumn{7}{l}{ SI (USA $\rightarrow$ USA) 51.97} \\
\hline
\end{tabular}

Source: based on own research.

Table 3. Volatility spillover table (airlines)

\begin{tabular}{|l|c|c|c|c|c|c|c|c|r|}
\hline & RYA & IAG & LHA & AF & UAL & AAL & DAL & LUV & $\begin{array}{c}\text { From } \\
\text { others }\end{array}$ \\
\hline RYA & 84.32 & 5.26 & 4.14 & 3.22 & 0.47 & 0.89 & 1.28 & 0.42 & 15.68 \\
\hline IAG & 4.50 & 76.70 & 7.63 & 6.61 & 0.95 & 1.19 & 1.50 & 0.93 & 23.30 \\
\hline LHA & 3.20 & 6.99 & 73.13 & 14.57 & 0.25 & 0.78 & 0.52 & 0.57 & 26.87 \\
\hline AF & 2.28 & 6.67 & 14.75 & 74.26 & 0.41 & 0.42 & 0.58 & 0.64 & 25.74 \\
\hline UAL & 0.44 & 0.49 & 0.36 & 0.48 & 54.86 & 19.64 & 19.29 & 4.45 & 45.14 \\
\hline AAL & 0.76 & 0.89 & 0.53 & 0.38 & 17.82 & 54.08 & 18.00 & 7.53 & 45.92 \\
\hline DAL & 0.75 & 1.13 & 0.33 & 0.47 & 17.22 & 17.70 & 51.69 & 10.72 & 48.31 \\
\hline LUV & 0.26 & 0.94 & 0.61 & 0.39 & 6.22 & 9.91 & 13.82 & 67.86 & 32.14 \\
\hline To others & 12.19 & 22.36 & 28.36 & 26.12 & 43.32 & 50.52 & 54.99 & 25.25 & SI 32.89 \\
\hline & \multicolumn{7}{|l|}{ SI (Europe $\rightarrow$ Europe) 19.96} & \multicolumn{7}{l}{ SI (USA $\rightarrow$ Europe) 2.94} \\
\hline
\end{tabular}

Source: based on own research.

The first such period is the global financial crisis, which was accompanied by many spectacular events, e.g. the bankruptcy of Lehman Brothers in August 2008. It lasted until the first half of 2009 when the global financial crisis deepened. It seems that the linkages between the analysed stock prices increased during the crisis, which is a characteristic phenomenon in times of turmoil. 


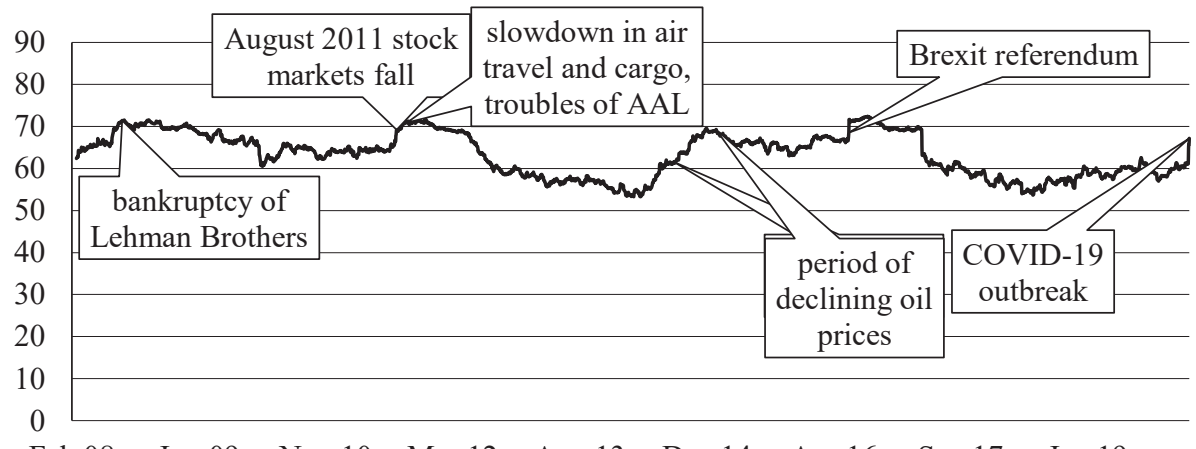

Feb.08 Jun.09 Nov.10 Mar.12 Aug.13 Dec.14 Apr.16 Sep.17 Jan.19

Fig. 2. Total returns spillovers among airlines stocks

Source: based on own research.

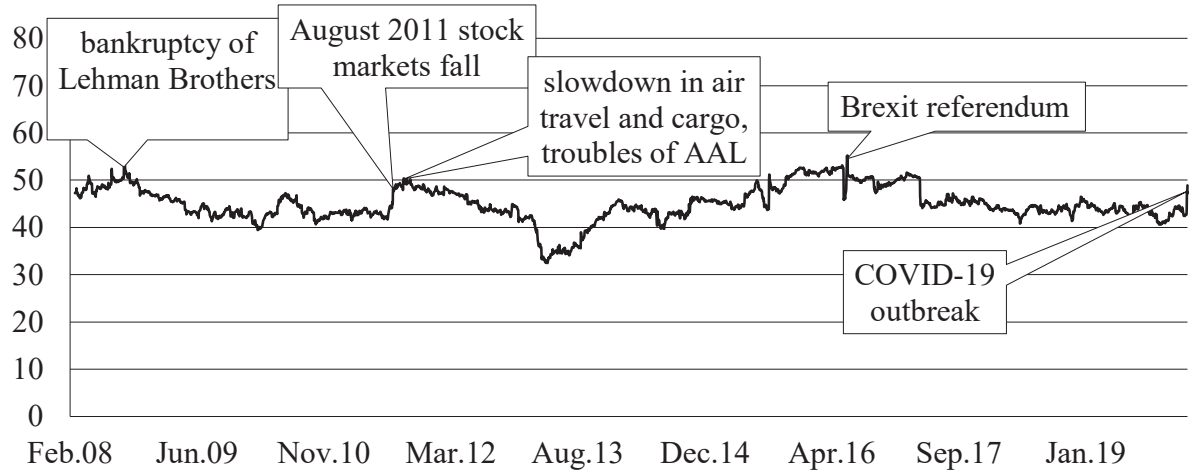

Fig. 3. Total volatility spillovers among airlines stocks

Source: based on own research.

A similar effect was triggered in the summer of 2011 when there were drops in the stock exchanges across the United States, Europe and Asia due to the European sovereign debt crisis and concerns over the downgraded credit rating of the United States. Moreover, a slowdown in air travel and cargo, and the troubles of American Airlines that occurred at that time could have been additional factors leading to increasing connectedness.

In the second half of 2014 there was an interesting period of a huge fall in the oil price. There were several causes for one of the most striking drops in the price of oil in recent history (for details, see Baumeister and Kilian, 2016). It is clear that connectedness between airlines' stock prices increased during this time.

Another spectacular event that affected the level of the index was the referendum regarding the UK's exit from the European Union. According to Stalnaker et al. 
(2018), during the uncertainty created by Brexit, airlines operating in the United Kingdom and European Union markets increased capacity as a result of growth in passenger traffic. Despite positive short-term results, there were some concerns that the slowing of GDP growth could change the true impact of the UK's plan to withdraw from the EU.

Last but not least, an increase in connectedness can be observed in the last days of the considered sample, which is undoubtedly associated with the outbreak of the coronavirus epidemic. Restrictions on air traffic in Europe and international flights from the United States have been gradually introduced. Passengers reduced travel, airlines sent employees on forced leave, and industry analysts predicted significant losses to aviation companies. All these events caused declines and high volatility of airlines' share prices.

\subsubsection{Considering crude oil and main capital market}

Since there are factors that affect revenues of all considered airline companies, it would be interesting to check whether the detected spillovers arose only as a result of these factors, or whether they are a real reflection of internal linkages in this market. Moreover, taking into account additional factors is interesting in itself. One can analyse how vulnerable airline stock price is to external shocks. Let us consider two common factors: crude oil prices and the situation in the main capital markets. The author constructed similar connectedness tables ${ }^{1}$ as in Section 3.2.1, but added to the system the West Texas Intermediate futures prices and the DJIA index returns and volatility. The DJIA index serves as a barometer of stock market performance, and crude oil reflects on jet fuel prices.

The study obtained several interesting findings. First of all, the main conclusions are consistent with the results in the previous section. Return spillovers are more intensive than volatility spillovers. Secondly, connectedness between the main capital market and the airline market is high. Directional return spillovers transmitted by the DJIA index to the airlines are relatively strong. One can formulate the following rather obvious conclusion: the main capital market affects airline stock prices. External shocks from the DJIA affect returns more than the volatility of the airline stock market. Moreover, and this is quite surprising, directional return and volatility spillovers transmitted by the crude oil market are at a much lower level than the remaining directional spillovers. Taking into account crude oil futures prices, one can ask whether the obtained results would be similar in the case of the spot prices. The author decided to verify this issue and it turned out that similar results ${ }^{2}$ were obtained. It is worth emphasizing that the results show that connectedness between daily returns and volatility of airline stock prices are a real reflection of internal

\footnotetext{
${ }^{1}$ Detailed results with the return and volatility spillover tables are available on request.

${ }^{2}$ We collected the daily data of West Texas Intermediate spot prices from the EIA (U.S. Energy Information Administration) database.
} 
linkages in this market and not a spurious result arising from a crude oil dynamics. Naturally this does not contradict the earlier observation that during a long period of dramatic oil price changes the spillover index can be higher due to the long-term effects of changing operating costs.

\section{Conclusion}

This study conducted a comparative analysis of the total and directional spillovers in the airline stock market. Using the Diebold and Yilmaz approach, the author measured a level of connectedness between the returns and volatilities for the major publicly traded airline companies in Europe and the United States. In this context, three main research questions were asked:

RQ1: Do airlines stock prices and volatilities react in the same manner to shocks coming from other regions as to the internal region shocks?

According to the results, the level of transatlantic return and volatility spillovers is much lower than internal spillovers. It was found that there is a regional division into two markets, since interactions are stronger for close competitors. These results are in line with the results of Gong et al. (2008). Moreover, connectedness between European airlines is weaker than between American ones.

RQ2: Are prices spillovers stronger, compared to the volatility spillovers?

Undoubtedly, one can say that total and directional spillovers are stronger in the case of returns. The contribution of spillovers of shocks across all asset classes to the total forecast error variance, represented by the spillover index, is weaker in the case of volatility, but it also seems significant. However, the dynamics of returns and volatility spillover indices appear to be similar. This result is therefore different from the results shown in the paper by Diebold and Yilmaz (2009). In their study of global stock market returns, spillovers display no bursts, but volatility spillovers display a sharp increase associated with crisis events. In this case, the values of the spillover indices remained quite stable during the analysed time span, however there were certain periods of moderate increase.

RQ3: What events lead to an increase in connectedness?

The results of this study show that an increase of connectedness historically occurred due to the global events that could lead to changes in the condition of airlines: namely issues linked with the condition of the global economy, long-term crude oil price change or events affecting political stability. Moreover, even though it was found that during a long period of dramatic oil price changes the spillover index can be higher, these results suggest that directional spillovers transmitted by the crude oil market are at a much lower level than the spillovers transmitted directionally from other airlines or the main stock market. Some of the previous studies devoted to the airline stock market and crude oil market linkages showed that the oil price is a significant factor and that fuel shocks triggered higher volatility. It was found that directional spillovers received by European and American airline 
stock markets from the oil market are rather weak compared to the internal return and volatility spillovers indices.

To sum up, the study results shed new light on the nature of return and volatility shocks transmission to the airline market, indicating the importance of internal connectedness and the impact of certain global events.

\section{References}

Alter, A., and Beyer, A. (2014). The dynamics of spillover effects during the European sovereign debt turmoil. Journal of Banking \& Finance, 42, 134-153.

Antonakakis, N. (2012). Exchange return co-movements and volatility spillovers before and after the introduction of euro. Journal of International Financial Markets, Institutions and Money, 22(5), 1091-1109.

Antonakakis, N., and Kizys, R. (2015). Dynamic spillovers between commodity and currency markets. International Review of Financial Analysis, 41, 303-319.

Awartani, B., and Maghyereh, A.I. (2013). Dynamic spillovers between oil and stock markets in the Gulf Cooperation Council Countries. Energy Economics, 36, 28-42.

Baruník, J., Kočenda, E., and Vácha, L. (2016). Asymmetric connectedness on the U.S. stock market: Bad and good volatility spillovers, Journal of Financial Markets, 27, 55-78.

Batten, J.A., Ciner, C., and Lucey, B.M. (2015). Which precious metals spill over on which, when and why? Some evidence. Applied Economics Letters, 22, 466-473.

Baumeister, Ch., Kilian, L. (2016). Understanding the Decline in the Price of Oil since June 2014. Journal of the Association of Environmental and Resource Economists, 3, 131-158.

Carter, D. A., and Simkins, B. J. (2004). The market's reaction to unexpected, catastrophic events: the case of airline stock returns and the September 11th attacks. The Quarterly Review of Economics and Finance, 44(4), 539-558.

Demirer, M., Diebold, F. X., Liu, L., and Yilmaz, K (2018). Estimating Global Bank Network Connectedness. Journal of Applied Econometrics, 33, 1-15.

Diebold, F. X., and Yilmaz, K. (2009). Measuring financial asset return and volatility spillovers, with application to global equity markets. The Economic Journal, 119, 158-171.

Diebold, F. X., and Yilmaz, K. (2012). Better to give than to receive: Predictive directional measurement of volatility spillovers. International Journal of Forecasting, 28, 57-66.

Diebold, F. X., and Yilmaz, K. (2014). On the network topology of variance decompositions: Measuring the connectedness of financial firms. Journal of Econometrics, 182(1), 119-134.

Diebold, F. X., and Yilmaz, K. (2016). Trans-Atlantic Equity Volatility Connectedness: U.S. and European Financial Institutions, 2004-2014. Journal of Financial Econometrics, 14(1), 81-127.

Gillen, D., and Lall, A. (2003). International transmission of shocks in the airline industry. Journal of Air Transport Management, 9(1), 37-49.

Gong, S. X. H., Firth, M., and Cullinane, K. (2008). International oligopoly and stock market linkages: The case of global airlines. Transportation Research Part E: Logistics and Transportation Review, 44(4), 621-636.

Hsu, C. (2017). How fuel price shocks affect airline stock returns: an empirical study of major US carriers. The International Journal of Business and Finance Research, 11(2), 51-59.

Kang, S. H., McIver, R., and Yoon, S-M. (2017). Dynamic spillover effects among crude oil, precious metal, and agricultural commodity futures markets. Energy Economics, 62, 19-32.

Killins, R. N. (2020). The impact of oil on equity returns of Canadian and U.S. Railways and airlines, North American Journal of Economics and Finance, 52. 
Kliber, A., and Włosik, K., (2019). Isolated Islands or Communicating Vessels? - Bitcoin Price and Volume Spillovers Across Cryptocurrency Platforms. Czech Journal of Economics and Finance (Finance a uver), 69(4), 324-341.

Koop, G., Pesaran, M. H., and Potter, S. M. (1996). Impulse response analysis in non-linear multivariate models. Journal of Econometrics, 74, 119-147.

Kristjanpoller, W.D., and Concha, D. (2016). Impact of fuel price fluctuations on airline stock returns. Applied Energy, 178, 496-504.

Mohanty, S., Nandha, M., Habis, E., and Juhabi, E. (2014). Oil price risk exposure: The case of the US travel and leisure industry. Energy Economics, 41, 117-124.

Nandha, M., and Brooks, R. (2009). Oil prices and transport sector returns: An international analysis. Review of Quantitative Finance and Accounting, 33, 393-409.

Parkinson, M. (1980). The extreme value method for estimating the variance of the rate of return. The Journal of Business, 53(1), 61-65.

Pesaran, M.H., and Shin, Y., (1998). Generalized impulse response analysis in linear multivariate models. Economics Letters, 58, 17-29.

Stalnaker, T., Usman, K., Taylor, A., and Alport, G. (2018). Airline economic analysis. 2017-2018 Edition, Oliver Wyman. Retrieved from https://www.oliverwyman.com/content/dam/oliverwyman/v2/publications/2018/January/Airline_Economic_Analysis_AEA_2017-18_web_FF.pdf

Yun, X., and Yoon, S. M. (2019). Impact of oil price change on airline's stock price and volatility: Evidence from China and South Korea. Energy Economics, 78, 668-679.

Zhou, X., Zhang, W., and Zhang, J. (2012). Volatility spillovers between the Chinese and world equity markets. Pacific-Basin Finance Journal, 20(2), 247-270.

\section{POWIĄZANIA POMIĘDZY NOTOWANIAMI AMERYKAŃSKICH I EUROPEJSKICH LINII LOTNICZNYCH - WNIOSKI Z METODY DIEBOLDA I YILMAZA}

Streszczenie: W artykule przedstawiono wyniki badania powiązań w świetle metody Diebolda i Yilmaza pomiędzy notowaniami najważniejszych linii lotniczych w Stanach Zjednoczonych i w Europie. Wyznaczono indeks powiązań dla dziennych zwrotów i zmienności dla całej próby oraz w ujęciu dynamicznym. Wyniki badania wskazują, że notowania wszystkich analizowanych linii lotniczych są ze sobą powiązane, ale istnieje wyraźny podział na dwa rynki. Powiązania między rynkiem europejskim a amerykańskim są znacznie słabsze niż efekty zarażania pomiędzy liniami lotniczymi z jednego rynku. Efekty zarażania są silniejsze dla zwrotów niż dla zmienności. Ponadto średni poziom indeksu powiązań jest wyższy w Stanach Zjednoczonych niż w Europie. Na zmiany poziomu powiązań w czasie miały wpływ wydarzenia $z$ otoczenia makroekonomicznego i rynku kapitałowego oraz długotrwała zmiana poziomu ceny ropy naftowej.

Słowa kluczowe: linie lotnicze, powiązania, metoda Diebloda-Yilmaza, zarażanie. 